\title{
UPAYA MENINGKATKAN HASIL BELAJAR PAI PADA POKOK BAHASAN SHALAT BERJAMAAH DENGAN MENGUNAKAN METODE ROLE PLAYING DI KELAS VII C SMPN 1 LIMPUNG
}

\author{
KISMATUN \\ SMPN 1 Limpung \\ e-mail: kismatunazza@gmail.com
}

\begin{abstract}
ABSTRAK
Penelitian ini bertujuan untuk meningkatkan hasil belajar siswa pada mata pelajaran agama islam pada pokok bahasan sholat berjamaah dengan menggunakan metode role playing. Subjek penelitian ini adalah siswa kelas VII C SMPN 1 Limpung Batang Jawa Tengah. Hasil penelitian menunjukan bahwa, penerapan metode bermain peran (Role Playing), dapat meningkatkan hasil belajar siswa. Hal ini terlihat pada saat pembelajaran siswa aktif dan antusias dalam melakukan shalat fardhu dengan berjamaah sesuai yang diperankan dikelompoknya. Dalam hal ini nilai aktifitas siswa yang diharapkan sesuai dengan KKM pun meningkat secara signifikan. Hal ini dapat diketahui dari nilai siswa pada pra siklus diketahui nilai siswa sebesar 71,6 lalu dilakukan penelitian tindakan didapatkan hasil tes akhir pada siklus I sebesar 80,2 dan meningkat pada siklus II dengan nilai 86. Sehingga dari hasil penelitian ini dapat memberikan perubahan nilai yang signifikan.
\end{abstract}

Kata Kunci: Metode Pembelajaran, Role Playing, Sholat Berjamaah

\section{ABSTRACT}

This study aims to improve student learning outcomes in Islamic religious subjects on the subject of prayer in congregation by using the role playing method. The subjects of this study were students of class VII C of SMPN 1 Limpung, Batang, Central Java. The results showed that, the application of the role playing method (Role Playing), can improve student learning outcomes. This can be seen when students are active and enthusiastic in performing fardhu prayers in congregation according to what is played in their group. In this case the value of student activities that are expected to be in accordance with the KKM also increases significantly. It can be seen from the student scores in the pre-cycle, it is known that the student's score is 71.6 then action research is carried out, the final test results in the first cycle are 80.2 and increased in the second cycle with a value of 86 . So from the results of this study can provide changes in the value significant.

Keywords: Learning Method, Role Playing, Congregational Prayer

\section{PENDAHULUAN}

Dalam kehidupan sehari-hari shalat merupakan suatu kewajiban bagi setiap umat Islam, karena shalat merupakan aspek yang paling dominan dalam menjaga dan menegakkan esensi hidup beragama Islam. Selain itu, shalat merupakan rasa syukur kepada Allah SWT sekaligus wujud pengabdian makhluk hidup kepada sang Khaliknya. Maka dari itu, pembelajaran tentang shalat harus disampaikan kepada anak dari sejak dini. Selain peran dari orang tua yang mengajarkan kepada anak-anaknya tentang shalat, sekolah juga berperan penting dalam mendidik dan mengajarkan tentang keagamaan, khusunya dalam hal pembelajaran shalat.

Mereka terlalu sibuk dengan pekerjaan duniawi mereka tanpa memerhatikan kewajibankewajiban mereka sebagai seorang Muslim. Sehingga hal tersebut menjadi salah satu penyebab terbelakangnya mental spiritual dalam kehidupan bermasyarakat, banyaknya penyelewenganpenyelewengan yang merugikan orang lain, seperti terjadinya tawuran antar warga, korupsi, perampokan, pencurian, pembunuhan, dan pemerkosaan. Semua itu dikarenakan pondasi iman dan ketakwaan kepada Allah sangat minim, khususnya dalamm elaksanakan shalat. Sebagaimana dalam al-Qur'an, Allah berfirman: 


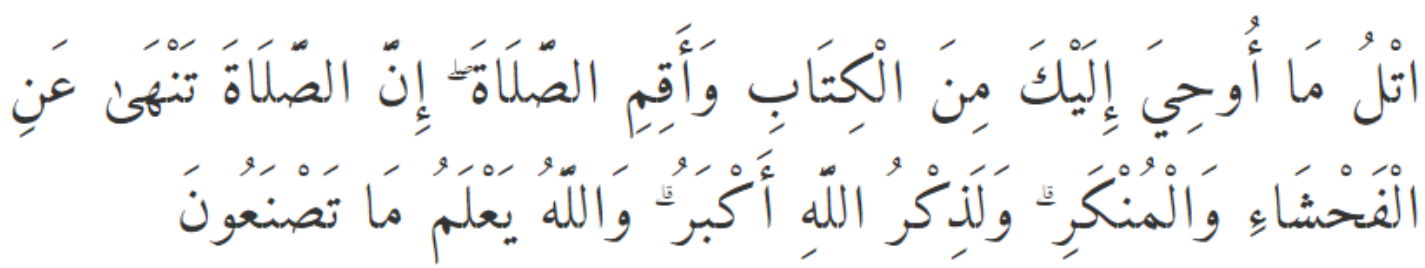

"Sesungguhnya shalat itu mencegah dari (perbuatan- perbuatan) keji dan mungkar. dan Sesungguhnya mengingat Allah (shalat) adalah lebih besar (keutamaannya dari ibadat-ibadat yang lain). dan Allah mengetahui apa yang kamu kerjakan." (QS.al- 'Ankabut [29]: 45)

Oleh karena itu, dalam lingkup pendidikan, guru berperan sebagai perantara pengetahuan. Guru menerjemahkan ilmu pengetahuan menjadi sebuah paket informasi yang menyenangkan sehingga siswa dapat menyerapnya dengan baik. Guru juga menciptakan pelajaran yang kreatif agar pengetahuan menjadi sesuatu yang menarik bagi siswa.

Oleh karenanya, metode yang digunakan dalam proses pembelajaran pun harus bisa mendapatkan hasil yang maksimal. Salah satu upaya untuk mewujudkan perilaku shalat dalam kehidupan bermasyarakat dimulai dari bimbingan dan arahan dalam lingkup keluarga dan sekolah dari sejak dini. Kontrol orang tua dan guru merupakan tugas utama yang harus diterapkan terhadap anak. Mereka sangat berperan penting untuk mewujudkan pendidikan tentang shalat. Namun pada faktanya di sekolah, masih banyak guru yang belum mampu menerapkan metode pembelajaran yang tepat, terutama dalam pelaksanaan pembelajaran mengenai shalat berjamaah.

Menurut Alim (2011) dan bukunya "Pendidikan Agama Islam Upaya pembentukan pemikiran dan kepribadian Muslim" mengatakan bahwa pendidikan Agama Islam dapat diartikan sebagai program yang terencana dalam menyiapkan peserta didik untuk mengenal, memahami, menghayati, hingga bagaiman ajaran Agama Islam serta mengikuti tuntunan untuk menghormati penganut agam lain dalam hubungannya, dengan kerukunan antar umat beragama hingga terwujud kesatuan dan persatuan antar umat beragama. Pendidikan agama tersebut dilakukan melalui kegiatan bimbingan, pengajaran atau pelatihan yang telah ditentukan untuk mencapai tujuan yang telah ditetapkan.

Metode Role Playing menurut Hasibuan dan moedjiono, (2008:27) adalah tiruan atau perbuatan yang hanya pura-pura saja. Dalam metode pembelajaran simulasi tidak hanya Role Playing saja melainkan ada, pisiko drama, sosio darama, dan permainan. Role Playing berasal dari kata sosio dan drama. Sedangkan menurut Masitoh dan Dewi (2011) bermain peran (Role Playing) merupakan jenis model simulasi yaitu permainan dalam bentuk dramatisasi, sekelompok siswa melaksanakan kegiatan tertentu yang telah diarahkan oleh guru.""

Berdasarkan hasil observasi yang telah dilaksanakan di kelas VII SMPN 1 Limpung, Batang Jawa Tengah, peneliti menemukan masalah-masalah yang terjadi dalam proses pembelajaran. Di antaranya adalah guru dianggap kurang tepat dalam menggunakan metode pembelajaran. Seperti penggunaan metode konvensional (ceramah, mencatat, dan mengerjakan soal-soal) dalam proses pembelajaran tentang shalat. Dengan metode tersebut, guru kurang mengembangkan dan memberikan kesempatan kepada siswa untuk aktif dalam mencari suatu jawaban dari suatu masalah yang ada dalam pembelajaran shalat. Dalam hal ini mengakibatkan nilai aktifitas siswa pun tidak sesuai dengan KKM yang diharapkan. Padahal, memberikan kesempatan kepada siswa untuk aktif pada proses pembelajaran dapat mempermudah dan membantu guru dalam menyampaikan materi, serta mempermudah siswa dalam memahami materi yang diberikan oleh guru.

Metode ini dapat mempermudah siswa dalam memahami materi yang diberikan oleh guru, karena metode bermain peran atau Role Playing ini berdasarkan pada pengalaman siswa, sehingga siswa mampu mengkaitkan atau menghubungkan dan mengimplementasikan hasil belajar dalam kehidupan sehari-hari. Dalam penelitian ini, peneliti menekankan pada hasil belajar siswa dalam pembelajaran PAI. Karena metode yang digunakan oleh guru PAI masih menggunakan metode konvensional. Hal ini menurut peneliti kurang dapat meningkatkan siswa 
dalam mengikuti pembelajaran sehingga siswa sering menyibukan diri dengan bermain-main atau bercanda di kelas. Dari pemaparan di atas, peneliti berminat untuk mengkaji metode role playing dalam upaya meningkatkan pemahaman praktik ibadah shalat pada siswa kelas VII. Oleh karena itu judul dari penelitian ini adalah "Upaya Meningkatkan Hasil Belajar PAI Pada Pokok Bahasan Shalat Berjamaah dengan Menggunakan Metode Role Playing di Kelas VII SMPN 1 Limpung Batang Jawa Tengah".

\section{METODE PENELITIAN}

Pada penelitian ini yang digunakan penulis yaitu penelitian tindakan kelas (Classroom Action Research). PTK sebagai suatu bentuk penelaahan melalui refleksi diri yang dilakukan oleh peserta kegiatan pendidikan tertentu dalam situasi sosial (termasuk pendidikan) untuk memperbaiki rasionalitas dan kebenaran dari (a) praktik-praktik sosial atau kependidikan yang mereka lakukan sendiri, (b) pemahaman mereka terhadap praktik-praktik tersebut, dan (c) situasi di tempat praktik itu dilaksanakan (Subiantoro, 2009). Penelitian tindakan kelas adalah sebagai suatu bentuk kajian yang bersifat reflektif oleh pelaku tindakan yang dilakukan untuk meningkatkan kemantapan rasional dari tindakan mereka dalam melaksanakan tugas, memperdalam pemahaman terhadap tindakan-tindakan yang dilakukan, serta memperbaiki kondisi di mana praktek pembelajaran tersebut dilakukan (Muslih,2009). Sedangkan teknik pengumpulan data menggunakan metode obsevasi,tes, wawancara dan dokumentasi. Hal ini sebagai upaya untuk mencermati kegiatan belajar sekelompok siswa dengan memberikan sebuah tindakan yang sengaja dimunculkan. Kegiatan tersebut dilakukan guru, kemudian guru beserta siswa, atau siswa dibawah bimbingan dan dengan arahan dari guru, dengan maksud untuk memperbaiki dan meningkatkan kualitas pembelajaran (E. Mulyasa,2004).

Subjek dalam penelitian ini adalah siswa kelas VII SMPN 1 Limpung Batang Jawa Tengah yang berjumlah 32 terdiri dari 13 orang siswa laki-laki dan 19 orang siswa perempuan. Pada penelitian ini, peneliti bertindak sebagai perancang dan pelaksana kegiatan. Peneliti membuat perencana kegiatan, melaksanaan kegiatan, mengumpulkan data menganalisis data. Berikut skema penelitian tindakan kelas

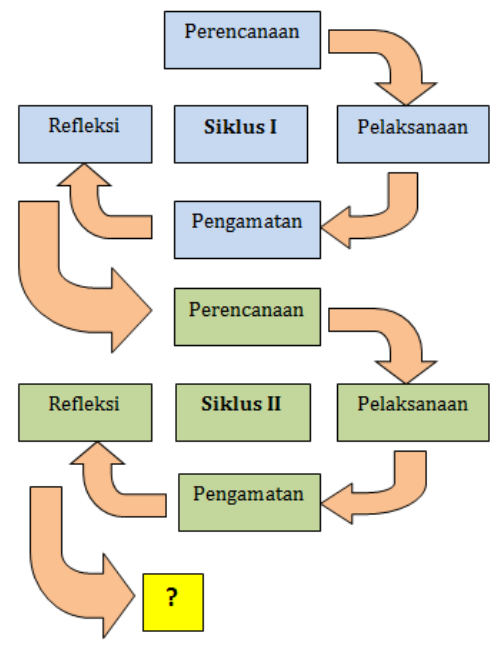

Gambar 1. Skema Penelitian Tindakan Kelas

\section{HASIL DAN PEMBAHASAN}

\section{Hasil}

\section{Pra Siklus}

Hasil pengamatan tersebut dapat dideskripsikan sebagai berikut:

a. Guru sudah berada di kelas ketika semua siswa sudah berada di kelas. Pada saat pelajaran dimulai masih banyak siswa yang belum siap belajar, yaitu masih banyak siswa yang mengobrol dan belum siap mendengarkan guru, tetapi ada juga sebagian siswa yang 
sudah siap belajar. Akhimya guru pun mengintruksikan kepada siswa untuk siap• siap dan berkonsentrasi untuk belajar dan menyiapkan segala peralatan belajar.

b. Metode yang digunakan guru adalah ekspositori, ceramah dan penguasaan guru menjelaskan materi dengan kondisi lebih banyak komunikasi sepihak (guru menjelaskan dan siswa mendengarkan) dan pendekatan yang digunakan guru selain buku pegangan dan LKS.

c. Waktu pembelajaran lebih banyak dipergunakan untuk mengerjakan soal-soal latihan di LKS dengan bimbingan yang sangat minim, siswa diminta mengerjakan soal di LKS sementara guru hanya duduk santai di depan kelas. Sesekali ada siswa yang bertanya tentang soal yang belum mereka pahami baru guru mendekati dan memberikan penjelasan, begitu seterusnya sehingga tidak terasa waktu pembelajaran pun telah berakhir, padahal hasil siswa pun belum diperiksa.

d. Guru memberikan kesempatan kepada siswa unutuk bertanya tentang materi yang sedang dibahas. Ada beberapa siswa yang belum paham dengan materi tersebut dan guru kembali menjelaskannya.

e. Ketika guru mulai pelajaran baru, masih terdapat siswa tidak memperhatiakan guru, masih ada yang ngobrol dan diam saja. Proses pembelajaran tidak langsung aktif, ini disebabkam siswa tidak berperan aktif dalam proses pembelajaran berlangsung. Ketika guru memberikan soal kepada siswa, banyak siswa yang keliru tentang jawabanya, masih malu untuk mengutarakannya, namun ada juga yang memjawab pertanyaan yang diberikan oleh guru. Hal ini yang menyebabkan kurang interaktifnya guru dan siswa dalam menjadikan kelas yang aktif.

f. Hasil belajar yang masih rendah. Hal ini terlihat dari nilai siswa yang belum mencapai nilai 70 pada pembelajaran PAI tentang shalat wajib (fardhu).

g. Masih banyak siswa yang belum mengerti dengan materi tersebut karena siswa malu dan tidak percaya diri yang mengakibatkan siswa tidak semangat untuk belajar dan mencobanya.

Materi yang akan dijadikan bahan ajar dalam tindakan penelitian adalah. Standar kompetensi (SK). Memahami tata cara shalat. Kompotensi Dasar (KD) menjelaskan ketentuan-ketentuan shalat wajib. Pemilihan materi tersebut, selain dari usulan dari guru PAI (kolabolator), juga hasil pretes yang temyata seluruh siswa memiliki nilai yang belum mencapai kriteria ketentuan minimal (KKM) yakni 70 di karenakan siswa masih malu dan gugup sesuai dengan data yang kami dapatkan dari guru kelas VII. 
Tabel 1. Data Nilai Siswa Pada Penelitian Pra Siklus

\begin{tabular}{|c|l|c|c|}
\hline \multicolumn{3}{|c|}{ Penilaian Hasil Tes Pra Siklus } \\
\hline No & \multicolumn{1}{|c|}{ Kelas } & Nilai \\
\hline 1 & AFNI DWI NASTUTI & VII & 70 \\
\hline 2 & AHMED DANANG ADZIM & VII & 80 \\
\hline 3 & AYUNING SUCI TRIHAPSARI & VII & 65 \\
\hline 4 & BAYU TRI WIJAYA & VII & 75 \\
\hline 5 & CAHAYA MAULIDAS5 & VII & 70 \\
\hline 6 & CAHYA AYUNING TYAS & VII & 80 \\
\hline 7 & EKA FHAMITA WIDODO & VII & 60 \\
\hline 8 & FAHRI ZHAFRAN AZZAKY & VII & 60 \\
\hline 9 & FAHMI ASYAFA & VII & 70 \\
\hline 10 & FINA AYU AMELIA & VII & 80 \\
\hline 11 & HABIBURRAHMAN RIDHO & VII & 85 \\
\hline 12 & HABIB ASSIDIQ & VII & 70 \\
\hline 13 & HANIFA DAFFA DIATMIKA & VII & 75 \\
\hline 14 & KAMILA PUTRI HANDAYANI & VII & 70 \\
\hline 15 & MELAR APRILIA PRADANI & VII & 70 \\
\hline 16 & MUHAMAH YAZID HALIMI & VII & 65 \\
\hline 17 & NABILA VEGA OKTAVIANI & VII & 70 \\
\hline 18 & NAJWA ANUGRAH RAHMADHANI & VII & 60 \\
\hline 19 & NUR AFNI FITRIANI & VII & 80 \\
\hline 20 & PRAMUDHITA RAMADHANI & VII & 85 \\
\hline 21 & RADITIA YUDHA PAHLAVI & VII & 80 \\
\hline 22 & RANAA OFANY ARMINA & VII & 80 \\
\hline 23 & RANI WIRDAYANI & VII & 70 \\
\hline 24 & RESKI ALIFFIAN & VII & 75 \\
\hline 25 & REZJA SASMITA & VII & 60 \\
\hline 26 & RIYAN SABIL ALFIYANSAH & VII & 60 \\
\hline 27 & RIZKS BRILLIYAN & VII & 60 \\
\hline 28 & SHAILA BRILLIYAN FAJRIA & VII & 75 \\
\hline 29 & SHERYL AURELLIA SAFINA & VII & 70 \\
\hline 30 & TAHTA YULFAHREENA & 71,5625 \\
\hline 31 & WIDYA FITRIANA & 70 \\
\hline 32 & ZAFFA ZIDNI ELMA & 70 \\
\hline & & & \\
\hline & & & \\
\hline
\end{tabular}

Tabel di atas adalah nilai siswa pra siklus, dapat dilihat dari tabel di atas bahwa rata-rata nilai siswa kelas VII adalah 71,5 dengan 3 nilai terendah adalah 60, 65 dan 70, sedangkan nilai tertinggi adalah 85. Hasil tabel di atas menunjukkan bahwa dari kelas VII nilai rata-rata siswa tergolong cukup.

Hasil obeservasi pra siklus dari nilai yang sudah ada sesuai dengan kemampuan siswa, dapat kita lihat dalam grafik berikut ini: 
Tabel 2. Kategori Penilaian

\begin{tabular}{|l|l|r|r|}
\hline Kategori Penilaian & Ket & Jumlah Siswa & Persentase \\
\hline Sangat Baik & $\geq 86$ & 0 & $0 \%$ \\
\hline Baik & $71-85$ & 13 & $41 \%$ \\
\hline Cukup Baik & $60-70$ & 19 & $59 \%$ \\
\hline Kurang & $41-59$ & 0 & $0 \%$ \\
\hline Sangat Kurang & $\leq 40$ & 0 & $0 \%$ \\
\hline
\end{tabular}

\section{Siklus I}

Dalam tahap observasi langsung bersamaan dengan pelaksanaan tindakan. Guru PAI (observasi) melakukan pengamatan langsung terhadap pelaksanaan pembelajaran PAI dengan menggunakan metode bermain peran selama proses pembelajaran berlangsung. Hasil pengamatan ini terbagi dua, yaitu pengamatan terhadap keterampilan guru (peneliti) dalam pembelajaran PAI dengan menggunakan metode bermain peran dan penggamatan terhadap aktifitas siswa dalam pembelajaran PAI dengan menggunakan metode bermain peran.

Aktifitas siswa dalam pembelajaran. Hasil pengolaan data aktifitas pada pertemuan siklus I dapat dilihat pada table berikut.

Tabel 3. Hasil Observasi Aktifitas Siswa Selama Proses Pembelajaran Siklus I

\begin{tabular}{|c|c|c|c|c|c|}
\hline No & Aspek yang di nilai & Jumlah Siswa & Total & Presentase & Ket \\
\hline & \multicolumn{5}{|c|}{ Aktifitas Siswa yang Sesuai dengan PBM } \\
\hline 1 & $\begin{array}{l}\text { Siswa Memperhatikan } \\
\text { Penjelasan guru }\end{array}$ & 6 & \multirow{3}{*}{20} & \multirow{3}{*}{$63 \%$} & \multirow{3}{*}{ Cukup } \\
\hline 2 & $\begin{array}{l}\text { Siswa serius mengerjakan } \\
\text { tugas yang diberikan }\end{array}$ & 7 & & & \\
\hline \multirow[t]{2}{*}{3} & $\begin{array}{l}\text { Siswa mampu } \\
\text { mengungkapkan ideidenya } \\
\text { dengan berani }\end{array}$ & 7 & & & \\
\hline & \multicolumn{5}{|c|}{ Aktifitas Siswa yang tidak Sesuai dengan PBM } \\
\hline 1 & Melamun & 4 & \multirow{3}{*}{12} & \multirow{3}{*}{$38 \%$} & \multirow{3}{*}{ Sangat Kurang } \\
\hline 2 & Mengobrol dengan teman & 6 & & & \\
\hline 3 & Melakukan pekerjaan lain & 2 & & & \\
\hline
\end{tabular}


Tabel 4. Nilai Hasil Perbandingan Penelitian Pra Siklus dan Siklus I

Penilaian Hasil Tes

\begin{tabular}{|c|l|c|c|}
\hline No & \multicolumn{1}{|c|}{ Siswa } & Pra Siklus & Siklus I \\
\hline 1 & AFNI DWI NASTUTI & 70 & 80 \\
\hline 2 & AHMED DANANG ADZIM & 80 & 80 \\
\hline 3 & AYUNING SUCI TRIHAPSARI & 65 & 75 \\
\hline 4 & BAYU TRI WIJAYA & 75 & 80 \\
\hline 5 & CAHAYA MAULIDAS5 & 70 & 80 \\
\hline 6 & CAHYA AYUNING TYAS & 80 & 85 \\
\hline 7 & EKA FHAMITA WIDODO & 60 & 85 \\
\hline 8 & FAHRI ZHAFRAN AZZAKY & 60 & 70 \\
\hline 9 & FAHMI ASYAFA & 70 & 80 \\
\hline 10 & FINA AYU AMELIA & 80 & 85 \\
\hline 11 & HABIBURRAHMAN RIDHO & 85 & 90 \\
\hline 12 & HABIB ASSIDIQ & 70 & 80 \\
\hline 13 & HANIFA DAFFA DIATMIKA & 75 & 85 \\
\hline 14 & KAMILA PUTRI HANDAYANI & 70 & 80 \\
\hline 15 & MELAR APRILIA PRADANI & 70 & 80 \\
\hline 16 & MUHAMAH YAZID HALIMI & 65 & 75 \\
\hline 17 & NABILA VEGA OKTAVIANI & 70 & 80 \\
\hline 18 & NAJWA ANUGRAH RAHMADHANI & 60 & 70 \\
\hline 19 & NUR AFNI FITRIANI & 80 & 80 \\
\hline 20 & PRAMUDHITA RAMADHANI & 85 & 85 \\
\hline 21 & RADITIA YUDHA PAHLAVI & 80 & 90 \\
\hline 22 & RANAA OFANY ARMINA & 80 & 80 \\
\hline 23 & RANI WIRDAYANI & 70 & 80 \\
\hline 24 & RESKI ALIFFIAN & 75 & 80 \\
\hline 25 & REZJA SASMITA & 60 & 75 \\
\hline 26 & RIYAN SABIL ALFIYANSAH & 60 & 80 \\
\hline 27 & RIZKS BRILLIYAN & 60 & 75 \\
\hline 28 & SHAILA BRILLIYAN FAJRIA & 75 & 80 \\
\hline 29 & SHERYL AURELLIA SAFINA & 70 & 85 \\
\hline 30 & TAHTA YULFAHREENA & 70 & 75 \\
\hline 31 & WIDYA FITRIANA & 70 & 75 \\
\hline 32 & ZAFFA ZIDNI ELMA & 80 & 85 \\
\hline & & 71,5625 & 80,15625 \\
\hline & & & \\
\hline
\end{tabular}

Dari hasil diatas terlihat bahwa nilai rerata tiap kelas mengalami suatu peningkatan menjadi 80,1 dimana nilai terendah kelas VII adalah 70. Dari hasil nilai diatas terdapat perubahan bentuk yang positif. meningkatkan nilai rata-rata kelas dan skor yang diperoleh untuk setiap kelas. Hal ini membuktikan bahwa pembelajaran dengan metode role playing efektif dalam meningkatkan nilai prestasi belajar siswa, terbukti dengan meningkatnya nilai baik setiap siswa serta nilai rata-rata yang diperoleh setiap kelas.

\section{Siklus II}

Tahap observasi langsung bersamaan dengan pelaksanaan tindakan. Guru pendidikan Agama Islam PAI (observasi) melakukan pengamatan langsung terhadap pelaksanaan 
pembelajaran PAI dengan menggunakan metode bermain peran selama proses pembelajaran berlangsung.

Berikut observasi kegiatan guru dan aktifitas siswa selama proses pembelajaran siklus II. Berdasarkan tindakan dan observasi pada pembelajaran pertemuan siklus II, diperoleh hasil berikut:

Hasil pengolahan data aktifitas siswa pada pertama siklus II dapat dilihat ditabel berikut:

Tabel 5. Aktifitas Siswa Selama Pembelajaran Siklus II

\begin{tabular}{|c|c|c|c|c|c|}
\hline No & Aspek yang di nilai & Jumlah Siswa & Total & Presentase & Ket \\
\hline & \multicolumn{5}{|c|}{ Aktifitas Siswa yang Sesuai dengan PBM } \\
\hline 1 & $\begin{array}{l}\text { Siswa Memperhatikan } \\
\text { Penjelasan guru }\end{array}$ & 10 & \multirow{3}{*}{25} & \multirow{3}{*}{$78 \%$} & \multirow{3}{*}{ Baik } \\
\hline 2 & $\begin{array}{l}\text { Siswa serius mengerjakan } \\
\text { tugas yang diberikan }\end{array}$ & 8 & & & \\
\hline \multirow[t]{2}{*}{3} & $\begin{array}{l}\text { Siswa mampu } \\
\text { mengungkapkan ideidenya } \\
\text { dengan berani }\end{array}$ & 7 & & & \\
\hline & Aktifitas & a yang tidak $S$ & suai de & ngan PBM & \\
\hline 1 & Melamun & 3 & \multirow{3}{*}{7} & \multirow{3}{*}{$22 \%$} & \multirow{3}{*}{ Sangat Kurang } \\
\hline 2 & Mengobrol dengan teman & 2 & & & \\
\hline 3 & Melakukan pekerjaan lain & 2 & & & \\
\hline
\end{tabular}

Tabel 6. Nilai Hasil Perbandingan Penelitian Pra Siklus, Siklus I, dan Siklus II

\begin{tabular}{|c|c|c|c|c|}
\hline \multicolumn{5}{|c|}{ Penilaian Hasil Tes } \\
\hline No & Siswa & Pra Siklus & Siklus I & Siklus II \\
\hline 1 & AFNI DWI NASTUTI & 70 & 80 & 90 \\
\hline 2 & AHMED DANANG ADZIM & 80 & 80 & 85 \\
\hline 3 & AYUNING SUCI TRIHAPSARI & 65 & 75 & 90 \\
\hline 4 & BAYU TRI WIJAYA & 75 & 80 & 85 \\
\hline 5 & CAHAYA MAULIDAS5 & 70 & 80 & 90 \\
\hline 6 & CAHYA AYUNING TYAS & 80 & 85 & 95 \\
\hline 7 & EKA FHAMITA WIDODO & 60 & 85 & 80 \\
\hline 8 & FAHRI ZHAFRAN AZZAKY & 60 & 70 & 85 \\
\hline 9 & FAHMI ASYAFA & 70 & 80 & 90 \\
\hline 10 & FINA AYU AMELIA & 80 & 85 & 80 \\
\hline 11 & HABIBURRAHMAN RIDHO & 85 & 90 & 85 \\
\hline 12 & HABIB ASSIDIQ & 70 & 80 & 80 \\
\hline 13 & HANIFA DAFFA DIATMIKA & 75 & 85 & 80 \\
\hline 14 & KAMILA PUTRI HANDAYANI & 70 & 80 & 90 \\
\hline 15 & MELAR APRILIA PRADANI & 70 & 80 & 95 \\
\hline 16 & MUHAMAH YAZID HALIMI & 65 & 75 & 85 \\
\hline 17 & NABILA VEGA OKTAVIANI & 70 & 80 & 85 \\
\hline 18 & NAJWA ANUGRAH RAHMADHANI & 60 & 70 & 80 \\
\hline 19 & NUR AFNI FITRIANI & 80 & 80 & 85 \\
\hline 20 & PRAMUDHITA RAMADHANI & 85 & 85 & 90 \\
\hline
\end{tabular}


SECONDARY : Jurnal Inovasi Pendidikan Menengah

Vol 2. No 1. Januari 2022 P-ISSN : 2774-8022, e-ISSN : 2774-5791

\begin{tabular}{|c|l|c|c|c|}
21 & RADITIA YUDHA PAHLAVI & 80 & 90 & 90 \\
\hline 22 & RANAA OFANY ARMINA & 80 & 80 & 90 \\
\hline 23 & RANI WIRDAYANI & 70 & 80 & 85 \\
\hline 24 & RESKI ALIFFIAN & 75 & 80 & 85 \\
\hline 25 & REZJA SASMITA & 60 & 75 & 85 \\
\hline 26 & RIYAN SABIL ALFIYANSAH & 60 & 80 & 80 \\
\hline 27 & RIZKS BRILLIYAN & 60 & 75 & 75 \\
\hline 28 & SHAILA BRILLIYAN FAJRIA & 75 & 80 & 80 \\
\hline 29 & SHERYL AURELLIA SAFINA & 70 & 85 & 90 \\
\hline 30 & TAHTA YULFAHREENA & 70 & 75 & 90 \\
\hline 31 & WIDYA FITRIANA & 70 & 75 & 85 \\
\hline 32 & ZAFFA ZIDNI ELMA & 80 & 85 & 90 \\
\hline & Jumlah & 2290 & 2565 & 2750 \\
\hline & Rata-Rata & 71,5625 & 80,15625 & 85,9375 \\
\hline
\end{tabular}

Dari hasil diatas terlihat bahwa nilai rerata tiap kelas mengalami suatu peningkatan menjadi 85,9 dimana nilai terendah kelas VII adalah 75. Dari hasil nilai diatas terdapat perubahan bentuk yang positif. Meningkatkan nilai rata-rata kelas dan skor yang diperoleh untuk setiap kelas. Hal ini membuktikan bahwa metode role playing dalam meningkatkan nilai prestasi belajar siswa, terbukti dengan meningkatnya nilai baik setiap siswa serta nilai rata-rata yang diperoleh setiap kelas.

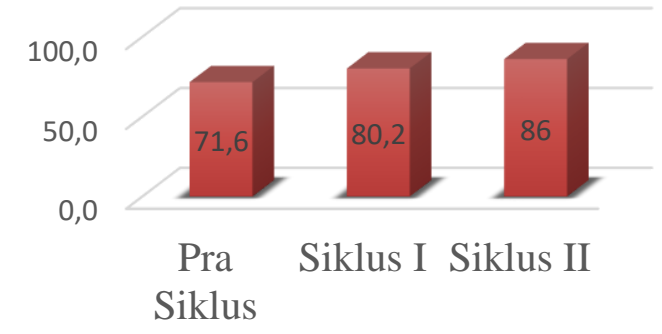

Gambar 2. Grafik Perbandingan Pra Siklus, Siklus I, dan Siklus II

\section{Pembahasan}

Dapat diketahui dari beberapa data diatas bahwa hasil belajar PAI dalam pembahasan implementasi pembelajaran shalat dengan menggunakan metode "Role Playing" atau bermain peran di SMPN 1 Limpung Jawa Tengah meningkat. Dan hasil belajar diatas membuktikan bahwa hasil belajar PAI siswa pada pokok pembahasan implementasi pembelajaran shalat teknik bermain peran dalam mengajar mampu merangsang siswa lebih bermotivasi. Mudah dan menyenagkan dalam proses pembelajaran dengan kata lain terbukti dengan menggunaka metode bermain peran (Role Playing), siswa lebih mudah dalam menerima/memahami pelajaran shalat yang disampaikan dan mampu mengimplementasikan pembelajaran shalat dalam kehidupan sehari-hari maupun disekolah dan dirumah.

\section{KESIMPULAN}

Berdasarkan analisis dan diskripsi data yang telah dipaparkan pada bab sebelumnya, maka peneliti dapat menarik kesimpulan bahwa pelaksanaan pembelajaran shalat dengan menggunakan metode (Role Playing) di SMPN 1 Limpung Kabupaten Batang Jawa Tengah telah dilaksanakan dengan baik, hal itu bisa dilihat dari:

1. Adanya konsistensi kegiatan belajar mengajar dalam kurikulum yang ditandai dengan adanya kesesuaian tujuan pembelajaran, bahan pengajaran yang diberikan, jenis kegiatan yang dilakukan. 
2. Keaktifan siswa dalam pembelajaran mengalami peningkatan sesuai dengan harapan, hal itu dapat dilihat dari dipahami dan diikutinya petunjuk-petunjuk pembelajaran dari guru, terlibatnya semua siswa dalam melaksanakan tugas belajar dan pemecahan masalah, munculnya keberanian untuk bertanya kepada sesama siswa atau guru.

3. Penggunaan metode bermain peran (Role Playing) dapat meningkatkan keberanian, kelancaran, kepekaan sikap siswa dalam implementasikan pembelajaran shalat.

\section{DAFTAR PUSTAKA}

Alim, Muhammad, 2011. Pendidikan Agama Islam (Upaya Pembentukan Pemikiran dan Kepribadian Muslim). Bandung: PT. Remaja Rosdakarya

Alim, Muhammad. 2006. Pendidikan Agama Islam: Upaya Pembentukan Pemikiran dan

Kepribadian Muslim. Bandung: Remaja Rosdakarya

Ambarjaya, Beni S. 2008. Model Model Pembelajaran Kreatif. Bandung: Tinta Emas

Anas, Muhammad. Mengenal Metode Pembelajaran. T.Tp. T.Th.

Aprilianty, Dewi. 2010. Pendidikan Agama Islam untuk SMP kelas VII. Bogor: CV Bina Pustaka.

Ardani, Moh. 2005. Akhlak Tasawuf, Nilai-nilai Akhlak/Budi Pekerti dalam Ibadah alam Tasawuf Ciputat: CV Karya Mulia

Ash-Shalah, Asrar dan Muhimmatuha. 1984. Rahasi Rahasia Shalat Al-Ghazali. Bandung: Karisma

Astori, Muhammad. 2008. Penelitian Tindakan Kelas, Bandung: CV Wacana Prima

Departemen Agama Provinsi Jawa Tengah. 2004. Fiqih Madrasah Tsanawiyah VII. Semarang: PT Karya Toha Putra

Ghony, M. Djunaidi. 2008. Penelitian Tindakan Kelas. Malang: UIN-Malang Press

Ibrahim, T. 2008. Penerapan Fiqih untuk Ielas VII Madrasah Tsanawiyah. Solo: PT Tiga Serangkai

IKIP Surabaya. 1989. Pengantar DidaktifMetodikKurikulum. Jakarta: Rajawali

Ilyas, Muhamad. Tuntunan Shalat Lengkap. Lingkar Media. T.Th.

Masitoh,dkk.2011.Strategi Pembelajaran TK.Jakarta:Universitas Terbuka.

Mulyasa, E. (2004). Kurikulum Berbasis Kompetensi.Rosda Karya.Bandung

Muslich,Masnur.(2009). Melaksanakan PTK Penelitian Tindakan Kelas itu Mudah.PT Bumi Aksara.Jakarta

Subyantoro. (2009). Penelitian Tindakan Kelas.CV. Widya Karya.Semarang 